\title{
'Lucky' Louisiana unprepared for Gustav
}

Hurricane Gustav, which made landfall just west of New Orleans on 1 September, had far less devastating effects than Hurricane Katrina three years earlier - on either the people or the land on which they live. But the third major hurricane to hit Louisiana's fragile wetlands in three years has made it clear that, although coastal recovery is high on the state's agenda, little has been done on the ground since 2005.

Just last month, Louisiana governor Bobby Jindal announced that the state would chip in $\$ 300$ million of its surplus funds for coastal restoration and flood protection. It is "the largest single commitment to coastal restoration ever made by any governor in Louisiana", says Chris Macaluso, a spokesman from the Governor's Office of Coastal Activities.

The funding swelled a pot of post-Katrina restoration money that had been secured, but mostly not spent, in time for Gustav. "Money started coming in, and what happened was another freakin' hurricane hit the coast," says Mark Kulp, a coastal geologist at the University of New Orleans in Louisiana. "Three years is not a lot of time to implement with all the bureaucracy."

In fact, one of the reasons Gustav did less ecological damage than expected may have been that it passed over the state's single remaining large barrier island, says Robert Twilley, a wetland ecologist at Louisiana State University in Baton Rouge. The intact Grand Isle acted as a buffer. "They were lucky," he says.

Still, Gustav has shown how the hurricane cycle is substantially shorter than the bureaucratic cycle of projects that are meant to make the coast healthier and less vulnerable to hurricanes.

Louisiana's coast is riddled with navigation and oil and gas pipeline channels that nibble away at the land from within. Levees and other flood-protection schemes along the Mississippi mean that the region no longer receives regular deposits of sediment from the river. An estimated 62 square kilometres of wetlands vanish each year simply from erosion.

Storms take even more: Katrina and Rita, which both hit in 2005 , wiped out 560 square kilometres. But this also convinced many officials that restoring such land is important for protecting settlements, including New Orleans, from the naked fury of a hurricane storm surge.

Before Katrina and Rita, the state and federal
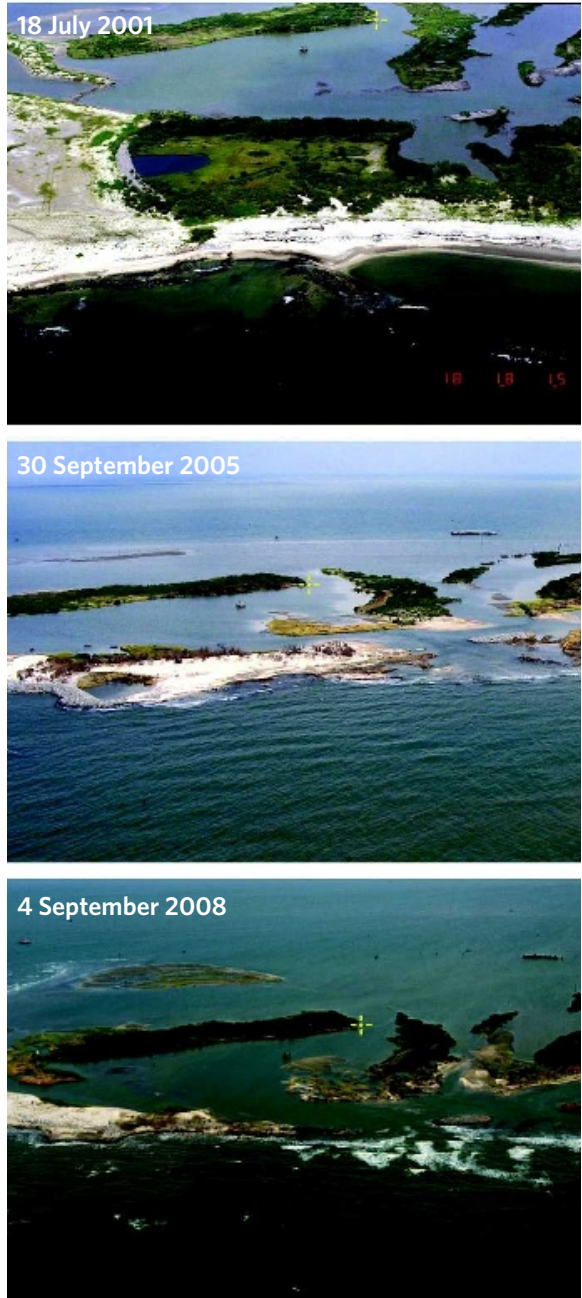

Erosion and hurricane damage have taken their toll on the Louisiana barrier island of East Timbalier.

government together spent about $\$ 75$ million a year on coastal restoration. A congressional act later that year secured an additional $\$ 510$ million over four years for both restoration and hurricane protection. In 2007, thenstate governor Kathleen Blanco assigned \$200 million of a state surplus to coastal restoration and hurricane protection.

But the money flows slowly through a gummy bureaucracy. In the case of the new Jindal money, Macaluso says, the governor couldn't commit any spare funds to coastal restoration until he had renegotiated with the federal government on repaying a large flood-protection grant.
Although hurricane protection and coastal restoration are increasingly being seen as two sides of the same coin, people always trump land."Because of the demand to fix the weak links in flood protection, a lot of the money spent post-Katrina - almost all of the money that has been made concrete - has gone into flood protection," notes Donald Boesch, president of the University of Maryland Center for Environmental Science in Cambridge and an expert on his native Louisiana coast. That makes sense, he says, but "it is going to be necessary not to lose sight of coastal restoration, or you'll end up with fortresses sitting in the Gulf of Mexico with no landscape around them".

Some restoration projects that predate Katrina include freshwater diversions from the Mississippi and pumping projects to spread sediment onto areas that are eroding. More ambitious, post-Katrina projects are mostly still on paper, including a substantial diversion-pipeline combination project near the hamlet of Myrtle Grove, up the Mississippi River from New Orleans.

There are some positive signs. The state finally has a comprehensive "master plan for a sustainable coast", adopted in June 2007. And a traditional over-reliance on hard structures such as levees, often introduced at the expense of wetlands, may be waning. In June, the US Army Corps of Engineers deauthorized the navigational channel known as MRGO (the Mississippi River Gulf Outlet); the structure is set to be closed off with 355,000 tonnes of rock. And the massive planned Morganzato-the-Gulf levee, approved last year by Congress, is being re-evaluated after cost estimates ballooned to more than $\$ 11$ billion.

Still, Kerry St. Pé, director of the BaratariaTerrebonne National Estuary Program in Thibodaux, has been agitating for eight years for a pipeline that would pump sediment from the Atchafalaya River, which flows out of the Mississippi, and from offshore, to rebuild wetlands in his area. It hasn't materialized, even after Katrina, Rita and now Gustav, which badly damaged St. Pés office roof. There is impatience in his voice when he says: "The one thing we know how to do in Louisiana is lay pipeline."

St. Pé may have to wait through another hurricane first. As Nature went to press, Hurricane Ike was looking likely to head into the Gulf of Mexico and strike somewhere in Texas or Louisiana as a major storm.

Emma Marris 